\title{
THE MACROINVERTEBRATE COLONIZATION OF LEAF BAGS: IS THERE A PATTERN?
}

\author{
R. M. V. Cortes', M. Abelho² \& S. B. Rebelo' \\ ${ }^{1}$ Universidade de Trás-os-Montes e Alto Douro, Apartado 202, Vila Real Codex, Portugal \\ 2 Departamento de Zoologia. Universidade de Coimbra, 3000 Coimbra, Portugal
}

Keywords: Colonization, stream macroinvertebrate communities, functional feeding groups, leaf litter

\section{SUMMARY}

There have been many studies of litter decomposition and the macroinvertebrates associated with litter. Nevertheless, the reasons why invertebrates colonize leaf bags are still a matter for discussion. Although invertebrates use leaves as food, it has been shown that they may use the leaf bag; as a substrate. In this study, we investigate whcther macroiiivertebrates colonize leaf bags despite aburidant natural leaf litter in the streams aiid whether they discriminate between leaves occurring naturally in the streams (Alnus glutinosa) and alien species ín this case, the South American Hura crepitans).

We found no differences in the relative abundance of chredders between Alnus and Hura leaf baga. In relation to the relative abundance of shredders in the leaf bags and in the streambed, we found all the possible combinations. In two streams there were no differences between the benthic samples and the leaf bags. in another stream. the relative abuiidance of shredders was higher in the benthic samples, and in a further stream, the relative abundance of shredders was higher in the leaf bags.

It seeins therefore, that when there ia an abundant supply of high quality food in the streams, there is no reason for the aggregation of shredders in the leaf bags.

\section{INTRODUCTION}

Coinparisori of invertebrate colonization and breakdown rates between different leaf species is an essential procedure to obtain information about three relevant aspects: a) the preference of invertebrate taxa for a specific type of litter, $b$ ) the energetic supply to the aquatic community through the leaf-processing continuum. aiid c) the nutritional quality of allochthonous detritus. This approach has already bcen used in the lberian strearn systems (e.g., IMBERT \& POZO, 1989; ESCUDERO $r$ t al., 1991). The same methodology has also been applied in thic geographical region to assess the ecological implications of extensive afforestations with the exotic species Eucalypus g/obulus. Comparison of processing rates, coloniration aiid consumption of eucalyptus and alder (Alnus glutinosa), one of the most coinmon riparian species in northern low-order streains, rnay allow predictions on the impact of eucalyptus afforestations on the energetic budgct of streams (POZO. 1993: BASAGUREN \& POZO, 1994: CORTES et al., 1994: CANHOTO \& GRAÇA, 1995).

The difference in texture and litter quality between alder and

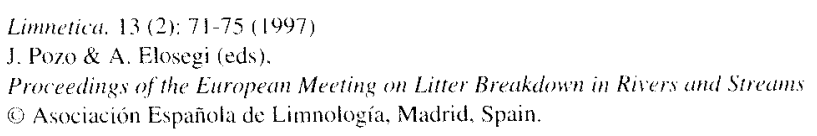

eucalyptus rnakes very predictable the distinction in decay rates, and also in the structure and composition of the invertebrate assemblages colonizing these leaves. A subject poorly investigated is the potential iinpact of an exotic species similar in leaf chemistry and decay rates to the natural occurring onec.

The colonization of natural aiid artificial leaf packs by macroinvertebrates in streams has been a matter of extensive discussion (BUNN, 1988; DOBSON, 1991; BASAGUREN \& POZO, 1994: MALMQVIST \& OBERLE, 1995). Some authors suggest that, by colonizing artificial leaf packs. invertebrates seek an additional food source (e.g., ROWE et al.. 1996). Many of these studies focus only on the proportion of shredders present in the leaf packs. without reference to the stream invertebrates (but see MALMQVIST \& OBERLE, 1995).

The objectives of the present study werc: (1) to compare the dynamics of invertebrate colonization on Hura crepitans, a South American species not occurring in Europe, with the Europenn Alnus glutinosa, and (2) to conipare invertebrates in leaf bags with invertebrates sampled in the stream benthos.

Since in headwaters leaf processing can be highly dependent on stream typology (HORTON \& BKOWN. 1991: POZO. 
1993; CORTES et al., 1995), and even on stream patches (CASAS, 1996), this investigation was carried out simultaneoucly in four similar low-order streains.

\section{STUDY SITES}

The study was carried out during autumn 1995 in 4 loworder streams (Tanha, Maíla, Azibais and Olo) located in the mountains of Vila Real, North Portugal (Douro watershed). The streams tlow through woodlands of pine afforestations (Pinus pinaster) and natural oak stands (Quercus pyrenaica). Riparian vegetation was a relatively intact corridor of alder (AInus glutinosa). The study area in each stream had relatively similar morphometry, substrate and water chemistry. Large boulders and cobbles with underlain gravel made the ctreambeds moderately retentive. Riffle areac dominated over shallow pools. In general, the water of the streams was poorly acidic and oligotrophic, although rivers Tanha and Maíla presented higher ion concentrations, probably as a consequence of short-scale agricultural practices (table 1)

\section{MATERIAL AND METHODS}

Seneccent leaves of Alnus glutinosa and Hura crepitans were collected just after abscission. Initial concentrations of nitrogen and phosphorouc (mean $\%+$ SD) for Alnus were respectively $2.15 \pm 0.12$ and $0.12 \pm 0.02(\mathrm{n}=6)$, and for Hura were $1.36 \pm 0.04$ and $0.23 \square .02(\mathrm{n}=5)$. Groups of air-dried leaves were weighed $(3 \pm 0.05 \mathrm{~g})$ and placed in $5 \mathrm{~mm}$ mesh plastic bags. Each bag was closed and tied to iron rodc deeply introduced into the streambed. Three bags of Alnus and two of Hura were randomly retrieved after 1,28 and 56 days.

Benthic invertebrates were sampled on days 0,28 and 56 using a hand-net (qualitative sampling). Samples were taken along 4 transects. in order to represent the dominant habitats.
Due to the high current velocity and frequent flooding events, some of the bags were lost during the experiment, and sampling of the stream bottom was not possible in stream 4 on day 28 .

Invertebrates removed from the leaf bags and collected in the stream bottom were identified to the lowest possible taxonomic level, counted and classified into 5 functional feeding groups: shredders, gathering-collectors, filtering-collectors, scrapers and predators (MERRITT \& CUMMINS, 1996; TACHET et al., 1987).

Because the number of individuals sampled in the streambed is not comparable to the number of individuals present in the leaf bags. data were transformed to species presence/absence. The Jaccard coefficient was used to determine similarity between samples and the resulting matrix was analyzed by cluster analysis (UPGMA). In order to compare the relative abundance of species, the Bray-Curtis coefficient was applied to a matrix of relative proportions (percentage similarity coefficient), and the resulting matrix analyzed as previously (BOESCH, 1977).

Statistical comparisons between the proportion of chredders present in the leaf bagc and campled in the streambed, and between the two leaf types were carried out by ANOVA (Zar. 1996).

\section{RESULTS}

In xtreams Tanha and Olo there was no difference between the proportion of shredders precent in the leaf bags and in the stream $(F<135, p>0.05)$. In streams Maíla and Azibais, the proportion of shredders present in the leaf bags and in the stream was significantly different $(\mathrm{F}>38, \mathrm{p}<0.05)$. However, in stream Maíla the relative abundance of shredders wac higher in the benthic samples while in stream Azibais, the relative abundance of shredders was higher in the leaf bags (fig. 1). There was no statistical difference between the two leaf species in any of the streams $(\mathrm{F}<135, \mathrm{p}>0.05)$.

Table 1. Physico-chemical characieristics of the stream water. Values are means with ranges in parentheses

\begin{tabular}{lcccc}
\hline & Tanha & Maíla & Azibais & Olo \\
\hline $\mathrm{pH}$ & $6.8(5.9-7.1)$ & $6.7(6.4-6.9)$ & $6.3(6.1-6.7)$ & $5.5(5.1-5.9)$ \\
Dissolved oxygen $(\%)$ & $100(92-107)$ & $97(92-106)$ & $98(91-112)$ & $101(94-115)$ \\
Temperature $\left({ }^{\circ} \mathrm{C}\right)$ & $9.6(7.8-11.2)$ & $10.2(9.1-11.8)$ & $9.7(8.8-10.5)$ & $7.8(7.1-8.8)$ \\
Conductivity $\left(\mu \mathrm{S} \mathrm{cm}{ }^{1}\right)$ & $62(44-72)$ & $72(58-83)$ & $31(30-32)$ & $12(11-13)$ \\
Nitrates $\left(\mathrm{mg} \mathrm{l}^{-1}\right)$ & $4.2(2.7-5.9)$ & $4.6(4.1-5.4)$ & $2.1(1.8-2.4)$ & $0.2(0.1-0.4)$ \\
Ammonia $\left(\mathrm{mg} \mathrm{l}^{-1}\right)$ & $0.02(0-0.10)$ & $0.03(0-0.10)$ & $0.02(0-0.09)$ & $0.01(0-0.03)$ \\
Phosphorus $\left(\mathrm{mg} \mathrm{l}^{-1}\right)$ & $0.02(0-0.02)$ & $0.01(0-0.03)$ & $0.01(0-0.01)$ & $0.01(0-0.02)$ \\
Current veiocity $\left(\mathrm{m} \mathrm{s}^{-1}\right)$ & $0.34(0.08-0.74)$ & $0.21(0.07-0.49)$ & $0.37(0.07-2.06)$ & $0.86(0.06-3.26)$ \\
Discharge $\left(\mathrm{m}^{3} \mathrm{~s}^{-1}\right)$ & $0.96(0.21-2.05)$ & $0.39(0.12-0.72)$ & $0.93(0.17-2.75)$ & $0.86(0.15-1.22)$ \\
\hline
\end{tabular}


Cluster analysis based on the Jaccard coefficient revealed 4 main groups (fig. 2). Samples from stream Azibais, excluding the benthic and the Almus samples from day 56, and the Hura samples from day 28 , form group 1 . Group 3 is formed by benthic samples from day 56 (streams Maíla and Olo) and Hura samples from day 1 (streams Tanha and Olo) and from day 28 (stream Maíla). The other groups are a miscellaneous collection of samples. Cluster analysis based on the percentage similarity coefficient revealed 3 main groups (fig. 3). Group 1 is mainly formed by samples from day 28 . Group 2 is mainly formed by samples from day 1, while group 3 is a miscellaneous collection of samples.

\section{DISCUSSION}

GAZZERA et al. (1991) found that both total number of individuals and shredder biomass were not significantly different in decomposing litter of elm and maple. However, the same was not found in studies comparing processing of alder and eucalyptus in low order streams (BASAGUREN \& POZO,
1994; CORTES et al., 1994; CANHOTO \& GRAÇA, 1995). This may be due to differences in processing rates, to different nutritional levels and to the content of refractory coinpounds.

Although no clear pattern arises from the performed cluster analyses, there is a tendency for highest similarity between samples from the same stream (fig. 2), probably meaning that the streams have distinct faunal compositions. Moreover, there seems to be a tendency for the difference between streams to be overcome by the difference between the temporal (sampling day) and the spatial (benthic/leaves) origin of the samples (fig. 3 ), when the relative percentage of invertebratec is taken into account.

In ttie present study, the relative percentage of invertebrates colonizing leaf species was similar, irrespective of the geographical origin of the leaves. It is possible that, when the exotic and indigenous species have similar nutritional quality (such as the case of Alnus and Hura), the differences between taxa colonizing both leaves are minimal. Many benthic taxa are food generalists that modify their diet according to food availability (e.g., HAWKINS, 1986; KING et al., 1987; WARREN, 1995).

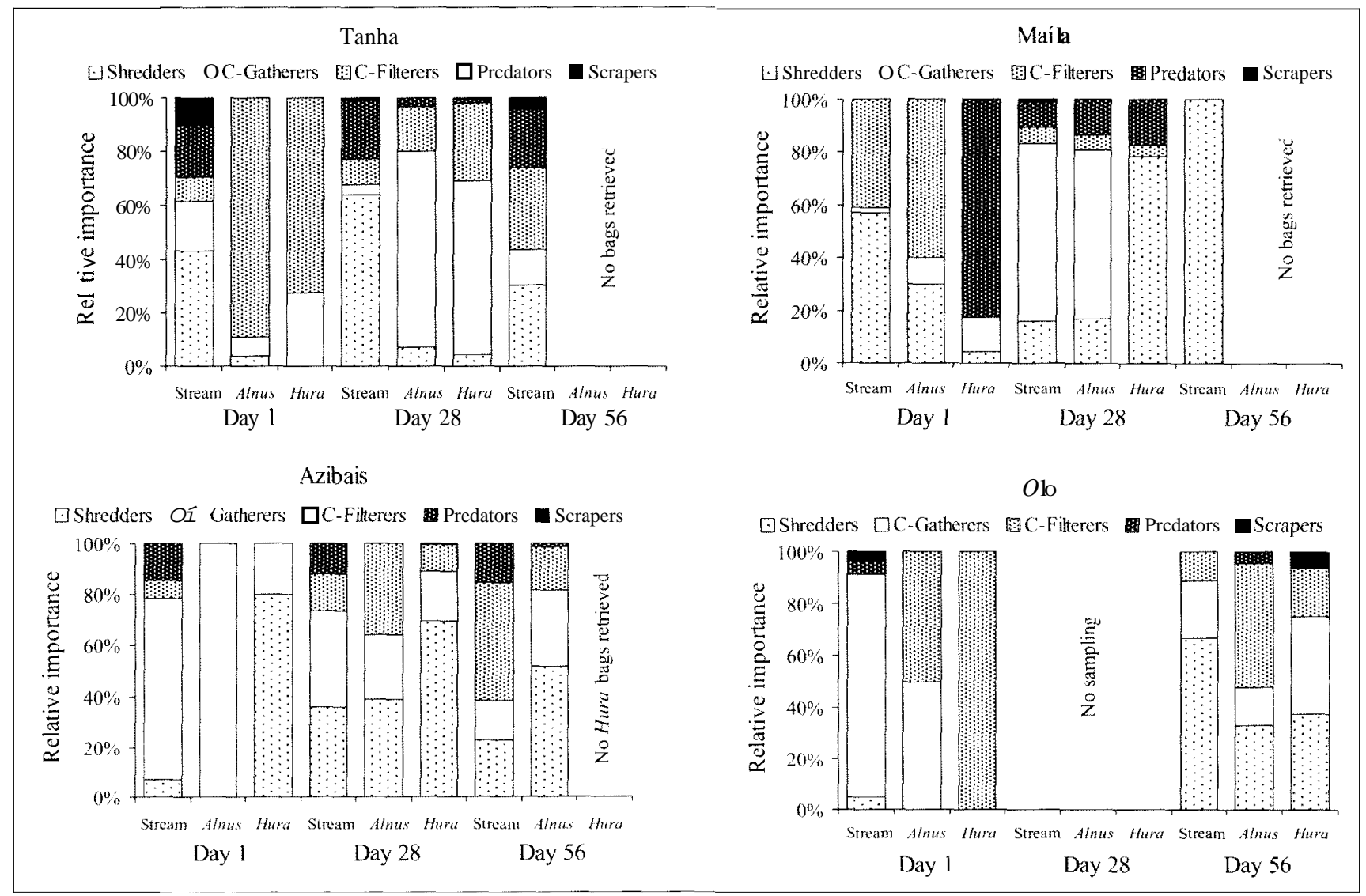

Figure 1. Percentage composition of the five functional feeding groups colonizing decaying Hura and Almus leaves and in the stream bottom 


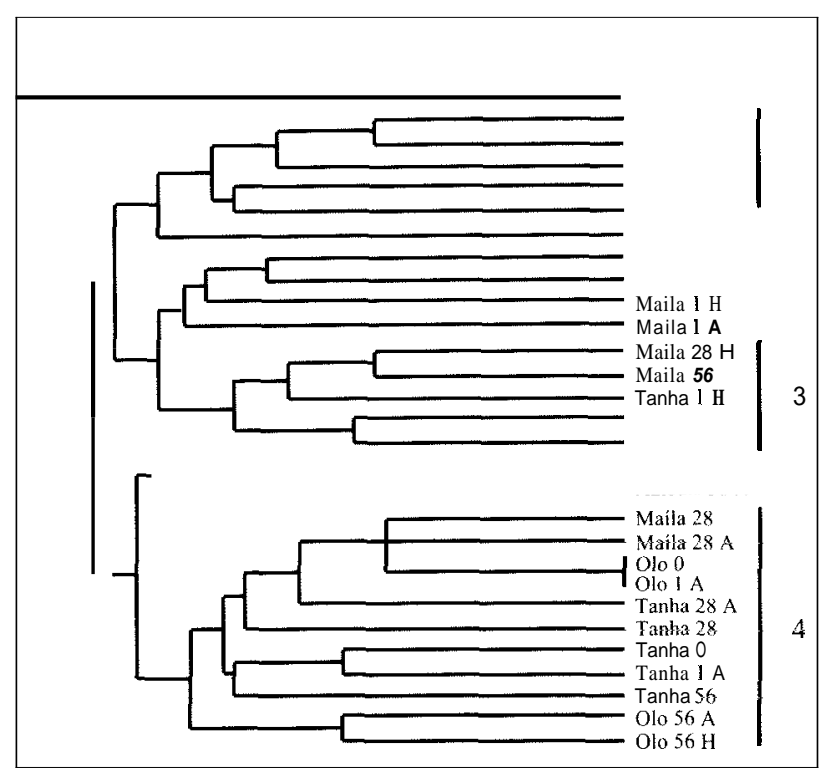

Figure 2. Cluster analysis based on the Jaccard coefficient (presence/absence data). Numbers refer to sampling dates. $\mathbf{A}$ and $\mathrm{H}$ stand for the leaf speciea. A date with no ietter refers to the benthic samples.

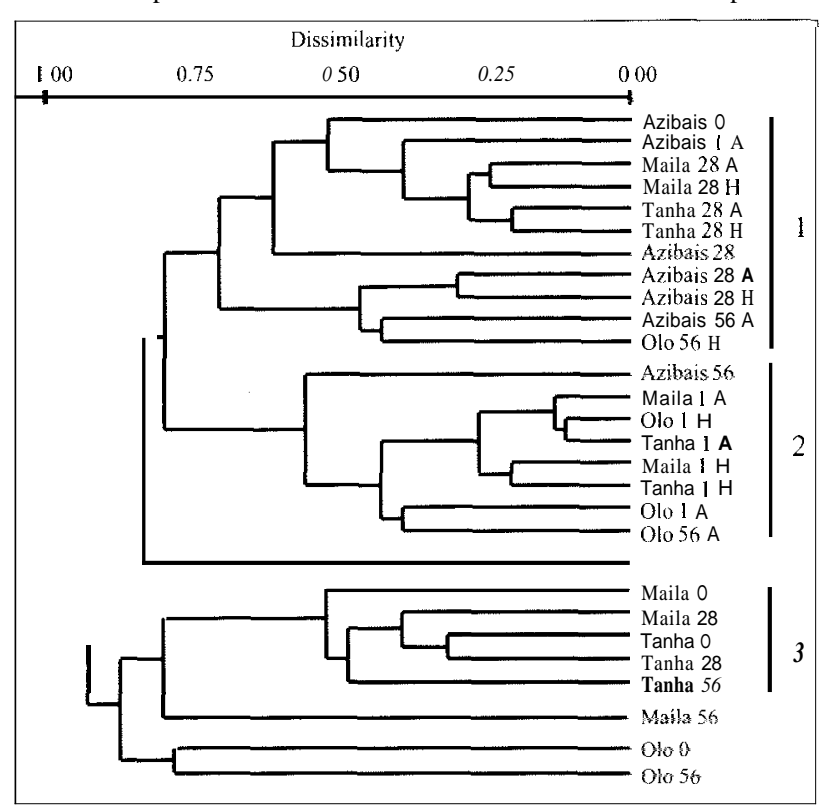

Figure 3. Cluster analysis based on the percentage similarity coefficient. Numhers refer to sampling dates. A and $\mathrm{H}$ stand for the leaf species. A date with no letter refers to the benthic samples.

Such generalist resource partitioning is particularly characteristic of taxa with similar mouthpart morphology, especially shredders (MIHUC \& MIHUC, 1995).

The question why shredders choose or do not choose the leaf bags when they have an abundant natural suppiy of leaf litter in the stream is not a simple one. Many factors can be invoived in this choice. When comparing colonization of decomposing pine needles and plastic strips by macroinvertebrates, GRAÇA \& PEREIRA (1995) found that the plastic strips were colonized first, although both numbers and biomasc of macroinvertebrates became higher in the needles by day 40 . However, shredders were no more abundant in the needles than in the plastic strips, suggesting that organic matter accumulations may have had an important role as shelter rather than as a food source in this case. REICE (1977) and DOBSON (1991) also reported that leaf packs provide food, attachment sites and refuge from direct current or extreme discharges.

In our study, shredders were proportionally more abundant in the leaves in just one case. This can be explained by the abundance of organic matter in the streams. Under these circumstances, invertebrates continuously feed and move between resource patches. According to the optimal foraging theory (BEGON et al., 1996), a consumer is expected to remain in a food patch while its profitability is high. Consistent with this theory, GRAÇA (1992) found that the shredders Asellus aquaticus and Gammarus pulex were more abundant in stream patches with high food quality. The fact that shredders did not move from the stream to the leaf bags suggests that, when our experiment was carried out, food (both quality and quantity) wac not a limiting factor in the streams.

In stream Azibais, shredders were more abundant in the leaf bags than in the stream. This may be related to the flooding events and high current velocity, that "cleaned" the streambed of naturally occurring litter. Moreover, the margins of this stream were very steep, which probably seduced the extent of shelter. In such a difficult environment, any additional supply of food and refuge is welcome.

In conclusion, our results suggest that when food availability in streams is high, there is no special reason for macroinvertebrates to aggregate in leaf bags.

\section{ACKNOWLEDGEMENTS}

This work was supported by the EC (contract CII-CT 930100VE) and by FCT (grant PBIC/C/BIA/2056/95). We thank IMAR (Coimbra) and the University of Trás-os-Montes e Alto Douro for the laboratory facilities. We thank Dr. M.A.S. Graça for the comments and suggestions on this manuscript.

\section{REFERENCES}

BASAGUREN, A. \& J. POZO, 1994. Leaf litter processing of alder and eucalyptus in the Agüera stream system (northern 
Spain). II. Macroinvertebrates associated. Arch. Hydrohiol., 132: 57-68.

BEGON, M., J.L. HARPER \& C.R. TOWNSEND, 1996. Ecology - Individuals, populations and Communities. 3rd edition. Blackwell. London.

BOESCH, D.F., 1977. Application of numerical classification in ecological investigation of water pollution. Virginia Institute of Marine Science. Special Scientific Report 77. Gloucester Point.

BUNN, S.E., 1988. Processing of leaf litter in two southern jarrah forest strearns, Western Australia: II. The role of macroinvertebratec and the influence of soluble polyphenols and inorganic sedirnent. Hydrohiologia, 162: 211-223.

CANHOTO, C. \& M.A.S. GRACA, 1995. Food value of introduced eucalypt leaves for a Mediterranean stream detritivore: Tipula lateralis. Freshwut. Biol., 34: 209-214.

CASAS, J.J., 1996. Environmental patchiness and procescing of maple litter in a backwater of a mountain stream: riffle area vs. debris dams. Arch. Hydrobiol., 136:489-508.

CORTES, R.M.V., M.A.S. GRAÇA \& A. MONZÓN, 1994. Replacement of alder by eucalypt along two streams with different characteristics: Differences on decay rates and consequences to the system functioning. Verh. Int. Ver: Limnol., 25: 1697 1702.

CORTES, R.M.V., M.A.S. GRACA, J.N. VINGADA \& S. VARANDAS DE OLIVEIRA, 1995. Stream typology and dynamics of leaf processing. Annls. Limnol., $31: 1$ 19-131

DOBSON, M., 1991. An assessment of mesh bags and plastic leaf traps as tools for studying rnacroinvertebrate assemblagec in natural leaf packs. Hydrohiologia, 222: 19-28.

ESCUDERO, A., S. SANZ, J.M. ARCO \& M.V. GARRIDO, 1991. Leaf litter decomposition in a mountain stream. Verh. Int. Ver. Limnol., 24: 1987-1993.

GAZZERA, S., K.W. CUMMINS \& G. SALMOIRAGHI, 1991. A comparison of leaf litter processing in Maryland and Italy. Verk. Int. Ver: Limnol., 24: 1703-1706.

GRACA, M.A.S., 1992. Starvation and food selection by strearn detritivores. Ciência Biológica - Ecology and Systemafics, 12: 27-36.

GRACA, M.A.S. \& A.P. PEREIRA, 1995. The degradation of pine needles in a Mediterranean stream. Arch. Hydrohiol.. 134: 119-128.
HAWKINS, C.P., 1986. Variation in individual growth rates and population densities of Ephemerellid mayfly. Ecology, 67: 1384-1395.

HORTON, R.T. \& A.V. BROWN, 1991. Processing of green American elm leaves in first, third and fourth order reaches of an Ozark stream. J. Freshwat. Ecol., 6: 115-120.

IMBERT, J.B. \& J. POZO, 1989. Breakdown of four leaf litter species and associated fauna in a Basque Country forested stream. Hydrohiologia. 182: 1-14.

KING, J.M., M.P. HENSALL-HOWARD, J.A. DAY \& B.R. DAVIES, 1987. Leaf pack dynamics in a southern African stream. Freshwut. Biol., 18: 325-340.

MALMQVIST, B. \& D. OBERLE, 1995. Macroinvertebrate effects on leaf pack decomposition in a lake outlet stream in northern Sweden. Nordic J. Freshwat. Res., 70: 12-20.

MERRITT. R.W.\& K.W. CUMMINS, 1996.An introduction to the aquatic insects of North America. 3rd edition. Kendall \& Hunt, Dubuque.

MIHUC, T.B.\& J.R. MIHUC, 1995. Trophic ecology of five shredders in a Rocky Mountain strearn. J. Freshwat. Ecol., 3: 209-2 16.

POZO, J., 1993. Leaf litter processing of alder and eucalyptus in the Agüera ctream systern (North Spain). 1. Chernical changes. Arch. Hydrohiol., 127: 299-317.

REICE, S.R. 1977. The role of animal associations and current velocity in sediment specific leaf litter decomposition. Oikos, 29: 357-365.

ROWE, J.M., S.K. MEEGAN, E.S. ENGSTROM, S.A. PERRY \& W.B. PERRY, 1996. Comparison of leaf processing rates under different temperature regimes in three headwater streams. Freshwat. Biol., 36: 277-288.

TACHET, H., M. BOURNAUD \& P. RICHOUX, 1987. Introduction à l'étude des macroinvertébrés des eaux douces. 3rd edition. C.R.D.P., Lyon.

WARREN, P.H., 1995. Estimating rnorphological, determined connectance and structure for food webs of freshwater invertebrates. Freshwat. Biol., 33: 213-221.

ZAR, J.H., 1996. Biostatistical analysis. 3rd edition. Prentice-Hall. London. 